\title{
REFRACTIVE ERRORS IN TYPE II DIABETIC PATIENTS
}

\author{
Shristi Shrestha ${ }^{1}$, Khem Raj Kaini ${ }^{2}$
}

\section{ABSTRACT}

INTRODUCTION: The prevalence of diabetes is increasing rapidly. Refractive error in the diabetic population is considered a main cause of visual impairment. So this study was conducted to find out the pattern of refractive errors in patients with type II diabetes mellitus in Western Nepal.

MATERIALAND METHODS: It was a hospital-based cross-sectional study. Three hundred forty eyes of one hundred seventy patients with type II diabetes underwent comprehensive eye examination including subjective and objective refraction and serum biochemistry.

RESULTS: The mean refraction was $-0.132 \pm 0.88$ D. Emmetropia was seen in $49.7 \%$ of the patients, hypermetropia in $22.6 \%$, myopia in $12.6 \%$, and astigmatism in $15 \%$ of the patients. Older age groups had more hypermetropic refractive error $(p<0.05)$. Female gender was a risk factor for hypermetropia $(p=0.042)$. Good glycemic control was seen in $49.7 \%$. There was statistically significant correlation between fasting blood sugar level and spherical equivalent refraction $(\mathrm{p}<0.05, \mathrm{r}=-0.115)$.

CONCLUSION: The present hospital-based study noted a refractive error in $50.3 \%$ among diabetic population in Pokhara with hypermetropia being the most common type (22.6\%) than myopia (12.6\%) and astigmatism (15\%).

KEYWORDS: Refractive error; Type II diabetes

1. Lecturer, Department of Ophthalmology, Manipal Teaching Hospital, Pokhara, Nepal

2. Professor, Department of Ophthalmology, Manipal Teaching Hospital, Pokhara, Nepal

For Correspondence

Dr. Shristi Shrestha

Lecturer,

Department of Ophthalmology, Manipal Teaching Hospital, Pokhara, Nepal

E-mail:shristi495@gmail.com 


\section{INTRODUCTION}

The prevalence of diabetes is increasing rapidly reaching epidemic proportions throughout both the developing and industrialized world. Although the prevalence of both type I and type II diabetes is increasing worldwide, the prevalence of type II diabetes is rising much more rapidly because of increasing obesity and reduced activity levels as countries become more industrialized. The total number of diabetic patients is projected to rise from 171 million in 2000 to 366 million in 2030 .

The US Centers for disease control and prevention reported that among individuals aged $\geq 20$ years with DM, $11 \%$ had visual impairment. In individuals with younger onset of diabetes, diabetic retinopathy was responsible for visual acuity of $<20 / 200$ in around $80 \%$ of the eyes, whereas in individuals with older onset diabetes, this was the case in one third. ${ }^{2}$ Refractive error in the diabetic population is considered a main cause of visual impairment. ${ }^{3}$

The occurrence of transitory refractive changes in diabetic patients has been recognized since 1873 . However, since that initial observation there have been conflicting reports of the nature of the changes and the reasons for them. ${ }^{4}$ Both myopic shifts ${ }^{5,6}$ and hyperopic shifts ${ }^{4,7}$ have been reported in patients with diabetes. Furthermore, no influence of diabetes on ocular refraction was observed in the Blue Mountain Study. ${ }^{8,9}$

The lens is a major modifiable determinant of refraction. The lenticular thickness increases with age but the ocular refraction actually becomes more hyperopic. ${ }^{10,11}$ The paradoxical increase in convexity of the lens with no myopic shift in ocular refraction with age, has been called the 'lens paradox' which can be explained by decrease in the equivalent refractive index of the lens with age, which compensates for the more convex shape of the ageing lens. ${ }^{12}$

The main cause of the refractive changes in diabetes is a change in the thickness of the lens, ${ }^{13-15}$ shape or a change in its refractive index. ${ }^{16}$ Several reports have shown increased lens thickness in diabetic patients. ${ }^{15-20}$ It could be suggested that if the change in shape of the lens is small, hyperopia will predominate during hyperglycemia due to a decrease in the refractive index of the lens. Alternatively, if the change in the shape of the lens is large in comparison to the decrease in refractive index of the lens, it will cause myopia. There may be no change if the variation in the shape of the lens is equal to the variation in the refractive index of the lens. So this study was done to determine the pattern of refractive errors in patients with type II diabetes mellitus.

\section{MATERIAL AND METHODS}

A hospital based cross-sectional study was conducted at Manipal Teaching Hospital from January 2011 to June 2012. Total 340 eyes of 170 patients were examined. All the patients with type II diabetes mellitus with clear optical media were included in the study. Eyes with corneal opacity, opaque media, pseudophakia, aphakia, history of prior surgery or patients with proliferative diabetic retinopathy, clinically significant macular edema and diabetic macular edema were excluded. All the subjects underwent comprehensive eye examination consisting of subjective and objective refraction, anterior and posterior eye examination. Visual acuity was determined using Snellen chart. Then the visual acuity was converted to log MAR equivalent. Refractive error was defined according to spherical equivalent (SE) refraction which was calculated as the spherical diopters plus one half of the cylindrical diopters. Myopia was defined as SE refraction $\leq-0.25 \mathrm{D}$. Hyperopia was defined as SE refraction $\geq+0.25 \mathrm{D}$. Emmetropia was defined as SE refraction between $-0.25 \mathrm{D}$ and +0.25 D. Grading of lens opacities was performed by using the Lens Opacities Classification System (LOCS III). Significant nuclear sclerosis was defined as nuclear opalescence of $\geq \mathrm{N} 2$. The level of metabolic control was evaluated by measuring glycosylated haemoglobin $\left(\mathrm{HBA}_{1 \mathrm{c}}\right)$, fasting blood sugar (FBS) and post-prandial blood sugar (PPBS). Subjects who had participated in this study were well informed about the purpose of the study and confidentiality was maintained. Data from both eyes were reported and analyzed using SPSS.

\section{RESULTS}

Of the 170 subjects, $71(41.8 \%)$ were women and $99(58.2 \%)$ were men. The mean age of these subjects was $51.09 \pm 10.55$ years. The older age groups had more hypermetropic refractive errors $(P<0.05)$. The monocular uncorrected visual acuity (UCVA) was better than or equal to $6 / 18$ in $281(81.6 \%)$ eyes.

Table 1: Distribution of monocular visual acuity

\begin{tabular}{|c|c|c|}
\hline Monocular UCVA & No. & Percentage (\%) \\
\hline $6 / 6$ & 164 & 48.2 \\
\hline $6 / 9$ & 43 & 12.7 \\
\hline $6 / 12$ & 40 & 11.8 \\
\hline $6 / 18$ & 34 & 10.0 \\
\hline $6 / 24$ & 28 & 8.2 \\
\hline $6 / 36$ & 19 & 5.6 \\
$6 / 60$ & 12 & 3.5 \\
\hline Total & $\mathbf{3 4 0}$ & $\mathbf{1 0 0}$ \\
\hline
\end{tabular}


Out of 340 study eyes, 169 (49.7\%) were emmetropic, 77 (22.6\%) were hypermetropic, 43 (12.6\%) were myopic and 51 $(15 \%)$ had astigmatism. The mean refraction was $-0.132 \pm 0.88$ D. Hypermetropia was more prevalent in females as compared to males. Gender was an independent risk factor for refractive error (chi-square test; $p=0.042$ )

Table 2: Distribution of spherical equivalent

\begin{tabular}{|c|c|c|}
\hline Spherical Equivalent(SE) & No. & Percentage (\%) \\
\hline-4.00 to -2.00 & 8 & 2.4 \\
\hline-1.75 to 0.00 & 236 & 69.4 \\
\hline+0.5 to +2.00 & 96 & 28.2 \\
\hline Total & $\mathbf{3 4 0}$ & $\mathbf{1 0 0}$ \\
\hline
\end{tabular}

Table 3: Genderwise distribution of refractive errors

\begin{tabular}{|c|c|c|}
\hline Refractive error & F & M \\
\hline & & \\
Astigmatism & $13.4 \%$ & $16.2 \%$ \\
\hline Hypermetropia & $30.3 \%$ & $17.2 \%$ \\
\hline Myopia & $12.0 \%$ & $13.1 \%$ \\
\hline Emmetropia & $44.4 \%$ & $53.5 \%$ \\
\hline Total & $\mathbf{1 0 0}$ & $\mathbf{1 0 0}$ \\
\hline
\end{tabular}

The mean duration of diabetes was $4.74 \pm 5.10$ years. The mean FBS was $145.01 \pm 66.13 \mathrm{mg} / \mathrm{dl}$, PPBS was $219 \pm 92 \mathrm{mg} / \mathrm{dl}$ and $\mathrm{HBA}_{1 \mathrm{c}}$ was $7.09 \pm 1.06 \% .169(49.7 \%)$ had good glycemic control.

\section{Table 4: Distribution of glycemic control}

\begin{tabular}{|c|c|c|c|}
\hline Glycemic control & Hba $_{1 \mathbf{1 c}} \mathbf{( \% )}$ & No. & Percentage(\%) \\
\hline Good & $5.6-7.0$ & 169 & 49.7 \\
\hline Fair & $7.1-8.0$ & 119 & 35.0 \\
\hline Unsatisfactory & $8.1-10.0$ & 48 & 14.1 \\
\hline Poor & $>10$ & 4 & 1.2 \\
\hline
\end{tabular}

There was a significant correlation between fasting blood sugar and spherical equivalent $(p<0.05, r=-0.115)$. With the increasing blood sugar levels, there was a slight myopic shift.

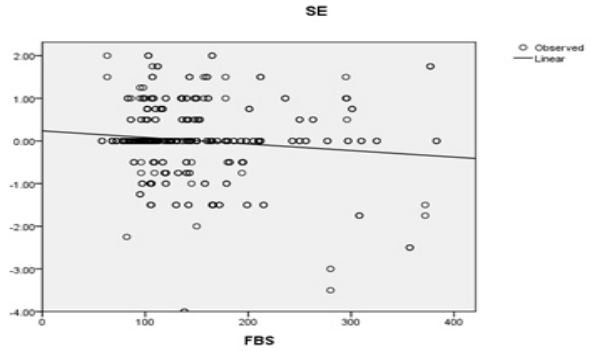

Fig. 1: Correlation between spherical equivalent and FBS in $\mathbf{m g} / \mathbf{d l}$

\section{DISCUSSION}

Refractive error in the diabetic population is considered one of the main cause of visual impairment. The present hospital based study found that the prevalence of all types of refractive errors in type 2 diabetes was about $50.3 \%$. The mean age among 170 subjects was $51.09 \pm 10.55$ years. There was a preponderance of males $(58.2 \%)$ over females $(41.8 \%)$. Female patients were associated with hyperopia as compared to male patients. Rani et al. also reported female gender to be associated with hyperopia. ${ }^{2}$ This may be because women's eyes have a shorter axial length and shallower anterior chamber depth than those of men and hence a higher probability of being hyperopic. ${ }^{22}$ The mean refraction was $0.132 \pm 0.88 \mathrm{D}$, whereas it was $-0.20 \pm 1.72 \mathrm{D}$ in Indian study ${ }^{2}$ and $-0.83 \pm 2.49$ D in Kinmen study. ${ }^{3}$

Table 5: Comparison of Distribution of Refractive Errors between the Present study and Various Published Studies (Diabetic Population)

\begin{tabular}{|c|c|c|c|c|c|}
\hline Study & $\mathrm{n}$ & Population & Myopia & Hyperopia & Astigmatism \\
\hline Present study & 170 & Diabetic & 25.2 & 45.0 & 29.8 \\
\hline Rani et al. $^{2}$ & 1080 & Diabetic & 21 & 39 & 47 \\
\hline Kinmen Study $^{3}$ & 547 & Diabetic & 57 & 24 & 88 \\
\hline Mwale et al. ${ }^{2 I}$ & 96 & Diabetic & 39.5 & 19 & 6.8 \\
\hline
\end{tabular}

Rani et $a l^{2}{ }^{2}$ and Sultanov et $a l^{21}$ also reported a higher prevalence of hypermetropia (33.2\%) as in this study whereas myopia was more prevalent than hypermetropia in Kinmen study. ${ }^{3}$ Ethnic variations are marked for the prevalence of refractive errors and this could possibly explain the higher prevalence of myopia in Kinmen study. ${ }^{3}$ This study revealed advancing age had hypermetropic shift. In order to prevent the confounding effect of nuclear sclerosis on the prevalence of refractive error, we excluded subjects with significant nuclear sclerosis (LOCS III $\geq \mathrm{N} 2$ ). Hyperopia and astigmatism was positively associated with age in Kinmen study, ${ }^{3}$ while Rani et $a l^{2}$ concluded advancing age as the most significant risk factor for all the refractive errors.

In our study $49.7 \%$ patients had good glycemic control. There was a significant correlation between fasting blood sugar and spherical equivalent. There was a slight myopic shift with increasing level of blood sugar. Mwale et al. revealed no significant correlation between both the types of refractive error and blood sugarlevel. ${ }^{21}$

As this study was hospital based, the patients did not represent a true sample of the population. Only 340 eyes of 170 patients were examined. Larger sample size would have been better to find the pattern of refractive errors. 


\section{CONCLUSION}

One of the important causes of visual impairment in the diabetic population is uncorrected refractive error. There are no available data on the prevalence of refractive error among diabetic patients in Nepal. However, in a study that was conducted in India, refractive error in the diabetic population over 40 years of age was as high as $60 \%$ and visual impairment due to refractive error in 1 eye was $6 \%$ and $3 \%$ in both the eyes. ${ }^{2}$ Extrapolating these estimates to approximately 511,000 subjects with diabetes mellitus in Nepal in $2010,{ }^{23}$ around 3 lakh subjects will have refractive error, around 30,000 subjects will have visual impairment in 1 eye and around 15,000 subjects will have visual impairment in both the eyes due to diabetes. Therefore, raising awareness and correcting refractive errors with suitable glasses will significantly reduce the magnitude of visual impairment in subjects with diabetes mellitus.

\section{REFERENCES}

1. Wild S, Reglic G, Green A, Sicree R, King H. Global Prevalence of Diabetes. Diabetes Care 2004;27:10471053.

http://dx.doi.org/10.2337/diacare.27.5.1047

http://dx.doi.org/10.2337/diacare.27.10.2569-a

PMid:15111519

2. Rani PK, Raman $R$, Rachapalli SR, Kulothungan $V$, Kumaramanickavel G, Sharma T. Prevalence of Refractive errors and associated Risk Factors in subjects with Type 2 Diabetes Mellitus. Ophthalmology 2010;117:11551162.

http://dx.doi.org/10.1016/j.ophtha.2009.10.025

PMid:20163863

3. Chen SJ, Tung TH, Liu JH, Lee AF, Lee FL, Hsu WM,et al. Prevalence and Associated factors of Refractive errors among Type 2 Diabetes in Kinmen, Taiwan. Ophthalmic Epidemiology 2008;15:2-9. http://dx.doi.org/10.1080/09286580701585736 PMid:18300083

4. Eva PR, Pascoe PT, Vaughan DG. Refractive changes in hyperglycemia: Hyperopia, not myopia. Acta Ophthalmol 1982;66:500-505

5. Duke Elder S. Changes in refraction in diabetes mellitus. Br J Ophthalmol 1925;9:167-187.

http://dx.doi.org/10.1136/bjo.9.7.382

http://dx.doi.org/10.1136/bjo.9.4.167 PMid:18168468

PMCid:PMC513478

6. Fledelius HC, Fuchs $J$, Reck A. Refraction in diabetics during metabolic dysregulation, acute or chronic. With special reference to the diabetic myopia concept. Acta Ophthalmol (Copenh) 1990;68(3):275-280.

http://dx.doi.org/10.1111/j.1755-3768.1990.tb01922.x
7. Giusti C. Transient hyperopic refractive changes in newly diagnosed juvenile diabetes. Swiss med Wkly 2003;133(1314):200-205. PMid:12811676

8. Guzowski M, Wang JJ, Rochtchina E, Rose KA, Mitchell P. Fiveyear refractive changes in an older population: the Blue Mountains Eye Study. Ophthalmology 2003;110:1364-70. http://dx.doi.org/10.1016/S0161-6420(03)00465-2

9. Shimizu N, Nomura H, Ando F, Niino N, Miyake Y, Shimokata H. Refractive errors and factors associated with myopia in an adult Japanese population. Jpn JOphthalmol 2003;47:6-12. http://dx.doi.org/10.1016/S0021-5155(02)00620-2

10. Saunders H. A longitudinal study of the age-dependence of human ocular refraction I. Age-dependent changes in the equivalent sphere. Ophthalmic Physiol Opt 1986;6:39-46. http://dx.doi.org/10.1016/0275-5408(86)90116-X http://dx.doi.org/10.1111/j.1475-1313.1986.tb00698.x PMid:3714274

11. Slataper FJ. Age norms of refraction and vision. Arch Ophthalmol 1950;43:466-481.

http://dx.doi.org/10.1001/archopht.1950.00910010475007

12. Moffat BA, Atchison DA, Pope JM. Explanation of the lens paradox. Optom Vis Sci 2002;79:148-50. http://dx.doi.org/10.1097/00006324-200203000-00008 PMid:11913840

13. Kato S, Oshika T, Numaga J, Kawashima H, Kitano S, Kaiya T. Influence of rapid glycemic control on lens opacity in patients with diabetes mellitus. Am J Ophthalmol 2000;130(3):354-355. http://dx.doi.org/10.1016/S0002-9394(00)00546-8

14. Pierro L, Brancato R, Zaganelli E, Guarisco L, Calori G. Corelation of lens thickness with blood glucose control in diabetes mellitus. Acta Ophthalmologica Scandinavica 1996;74:539541. http://dx.doi.org/10.1111/j.1600-0420.1996.tb00730.x PMid:9017037

15. SaitoY, Ohmi G, Kinoshita S, Nakamaura Y, Ogawa K, Harino S,et al. Transient hyperopia with lens swelling at initial therapy in diabetes. British JOphthalmology 1993;77:145-148. http://dx.doi.org/10.1136/bjo.77.3.145

16. Weimer NGM, Dubbleman M, Kostense PJ, Ringens PJ, Polak $B C P$. The influence of diabetes mellitus type I and type II on the thickness, shape and equivalent refractive index of the human crystalline lens. Ophthalmology 2008;115:1679-1686. http://dx.doi.org/10.1016/j.ophtha.2008.03.019 PMid:18486214

17. Fledelius HC, Miyamoto K. Diabetic myopia is it lens induced? An oculometric study comprising ultrasound measurements. Acta Ophthalmol (Copenh) 1987;65:469-73. http://dx.doi.org/10.1111/j.1755-3768.1987.tb07025.x 
18. Logstrup N, Sjolie AK, Kyvik KO, Green A.Long term influence of insulin dependent diabetes mellitus on refraction and its components: a population based twin study. $\mathrm{Br} J$ Ophthalmology 1997;81:343349. http://dx.doi.org/10.1136/bjo.81.5.343

19. Sparrow JM, Bron AJ, Brown NA, Neil HA. Biometry of crystalline lens in early onset diabetes. Br J Ophthalmology 1990;74:654-660. http://dx.doi.org/10.1136/bjo.74.11.654

20. Sparrow JM, Bron AJ, Brown NA, Neil HA. Biometry of crystalline lens in late onset diabetes: the importance of diabetic type. Br J Ophthalmology 1992;76:428-433.

http://dx.doi.org/10.1136/bjo.76.7.428

http://dx.doi.org/10.1136/bjo.76.1.25

21. Mwale C, Karimurio J, Njuguna M. Refractive errors in Type 2 diabetic patients. East African Medical Journal 2007;84:259263. PMid:18254467
22. Wong TY, Foster PJ, Ng TP. Variation in ocular biometry in an adult Chinese population in Singapore: the Tanjong Pagar Survery. Invest Ophthalmol Vis Sci 2001;42:7380. PMid:11133850

23. Shaw JE, Sicree RA, Zimmet PZ. Global estimates of the prevalence of diabetes for 2010 and 2030. Diabetes Research and clinical practice 2010;87:4-14

http://dx.doi.org/10.1016/j.diabres.2009.10.007 PMid:19896746

23. Shaw JE, Sicree RA, Zimmet PZ. Global estimates of the prevalence of diabetes for 2010 and 2030. Diabetes Research and clinical practice 2010;87:4-14. http://dx.doi.org/10.1016/j.diabres.2009.10.007 PMid:19896746 